\title{
Improving fruit quality of "Anna cv." apple trees grown on Malus rootstock by some bio compounds
}

\author{
Yehia M.M; Abd El BaryA. and Azza, I. Mohamed. \\ Deciduous fruits Department, Horticulture Res. Institute, Agric. Res; Centre, Giza, Egypt. \\ Corresponding author: dodi1961us@hotmail.com
}

\begin{abstract}
This study was conducted during 2013 and 2014 season's atfisha village, Mansoura Governorate to improve fruit quality of Anna apple trees. Treatments included that mixture ${ }_{1}$ content (Biolab) at $1 \mathrm{ppm}$ \{low concentration\}; mixture ${ }_{1}$ with high concentration at $2 \mathrm{~L} / 600$ liters water; mixture ${ }_{1}(\mathrm{Low}+\mathrm{high})$ concentrations; mixture ${ }_{2}$ content (Anti-stress) at $1 \mathrm{ppm}$; mixture ${ }_{2}$ with high concentration at $2 \mathrm{~L} / 600$ liters water; mixture ${ }_{2}$ (low+ high) concentrations; Pepton at $1 \mathrm{ppm}$; Pepton with high concentration at $2 \mathrm{~g} /$ liter water and control. All treatments sprayed three times at the mid of March, April and May. Results indicated that, mixture 2 (low + high) concentrations and Pepton treatments gave the best significant fruit number per tree. Mixture 2 (low + high) concentrations; pepton and mixture ${ }_{1}$ indicated the highest significant yield. Mixture ${ }_{1}$ gave the highest significant fruit weight. Acidity percentage decrease significantly with bio-compounds treatments than the control. Mixture $_{2}$ (low+ high) concentrations; mixture ${ }_{1}$ with high concentration and mixture ${ }_{2}$ had more pronounced positive affect on fruit color. The highest significant total phenols with control treatment. Total indoles were the highest with pepton. Total protein were the highest mixture 2.Leaves SDS-PAGE revealed total of 24 common bands (monomorphic bands) were detected while, the remaining twenty bands were polymorphic with $45.45 \%$ polymorphism. This variation was found between present or absent bands with different treatments may be due to the differences between improving fruit quality of Anna apple cultivar. Isozymes bands with poly phenol oxidase and peroxidase and were varied between treatments under study. It can be recommended that spraying with bio compound are improving fruit quality of Anna apple cultivar.Mixture ${ }_{2}$ \{low and high $\}$ with concentration $\{1.0 \mathrm{ppm}+2 \mathrm{~L} / 600$ liter water $\}$; Mixture 1 with concentration $1 \mathrm{ppm}$ and pepton with concentration 1000ppm are improving yield and fruit quality.
\end{abstract}

Key words: bio-compounds;Biolab; Anti-stress; Pepton; SDS-PAGE; Isozymes; poly phenol oxidase and peroxidase.

\section{Introduction}

Apple (Malusdomestica,Brokh)is considered the most important deciduous fruit in the world .In Egypt; "Anna" represents the main cultivated apple variety in Egypt (Saeid and Kalil, 1992). It is hybrid between "Red Hadassiya" and "Golden Delicious" apple cultivars. This variety has many advantages such as low chilling requirement, an early bearing and a high yield as compared with the local apple varieties. The cultivated total area in Egypt reach 72616 Feddans produced about 629613 tons (Ministry of Agriculture, 2013).

Anna apple cultivar is considering un-competitor cultivarin shape or test compared with introduce apple cultivars. Therefore, it is important to improve its fruit quality.

Polyamines are low molecular weight aliphatic amino compounds existent at every place in plants. They have been associated with growth and tissue differentiation (Franco Mora etal., 2005).

Amino acids are particularly important for stimulation cell growth. They act as buffers which the help to maintain favorable $\mathrm{pH}$ value within the plant cell, since they contain both acid and basic groups; they remove the ammonia from the cell. This function is associated with amide formation, so they protect the plants from ammonia toxicity. They can serve as a source of carbon and energy, as well as protect the plants against pathogens. Amino acids also function in the synthesis of other organic compounds, such as protein, amines, purines and pyrimidines, alkaloids vitamins, enzymes, terpenoids and other \{Veleroetal., 2002\}.

Also, Goss (1973) and Hass (1975), stated that the biosynthesis of cinamicacids (which are the starting materials for the synthesis of phenols) are derived from phenylalanine and tyrosine. Tyrosine is hydroxyl phenol amino acid that is used to build neurotransmitters and hormones. Moreover, Mohamed and Khalil (1992) indicated that promotive effect of amino acids on ornamental and medicinal plants. Treatment with amino acids was accompanied by a pronounced accumulation of other organic solutes (Saccharides, proteins and total amino acids); moreoverthey increase to some extent salt tolerance of plants through osmo-regulation (Silvaira etal., 2003).

Application of organic $\mathrm{N}$ (as pepton) caused significant increase in $\mathrm{NO}_{3}-\mathrm{N}$ production in nitrification samples. The increases in $\mathrm{No}_{3}-\mathrm{N}$ generally represented a low proportion of the added pepton-N (Adams 1986).Moreover, Growth and flowering parameters were significantly promoted by 
increasing the concentration of pepton (Soad etal., 2010).Also, amino acids (in form of pepton as commercial product) had a positive effect on productivity and fruit quality of Florida Prince peach trees (El-Razek and Saleh 2012).

Therefore, the aim of the present study is to improve fruit quality of Anna apple cultivar by spraying some bio compounds.

\section{Materials and Methods}

The present study was conducted during two successive seasons 2013 and 2014 on Anna apple trees budded on Malus rootstock in a private orchard at Fisha village, Mansoura Governorate. Trees were five - years - old and grown in the clay soil under flood irrigation system, spaced $2.5 * 2.5 \mathrm{~m}$, vase trained and subject to cultural practices recommended by ministry of agricultural. Thirty trees were considered to conduct this study in both seasons. Three replicates for each treatment were used. The chosen trees had uniform vigor and adopted in complete randomly block design.

Bio compounds concluded that:-

* Mixture 1 content (Biolab): Acrylet organic 15\%, Protein enzyme $25 \%$, Poly amino acid enzyme $30 \%$ and inert ingredient $30 \%$ ).

*Mixture 2 content (Anti-stress): Acrylet organic $10 \%$, Polypeptide enzymes $15 \%$, Protein enzyme $20 \%$, Poly-amino acid enzyme $20 \%$, inert ingredient 29\%, Vitamin A 1000 L.U., Vitamin $\mathrm{K}_{3} 0.15$ gm/liter).

*Pepton: (Aspartic 3.29\%, Tyrosin 0.52\%, Glutamic $8.18 \%$, Glycin $2.03 \%$, Alanine $2.26 \%$, Valine $2.51 \%$, Isoleucine $1.11 \%$, leucin $1.75 \%$, Arginine $4.64 \%$, Histidine $0.56 \%$, Proline $3.96 \%$, Phenyl Alanine $0.99 \%$, Serine $4.99 \%$, Threonine $3.57 \%$, organ nitrogen $12 \%$ and Potassium oxide $3.50 \%$, typical amino acids profile (\%) WW) at $1000 \mathrm{ppm}$.

Treatments concentrations were used as following:-

Mixture: It spread with low concentration at $1 \mathrm{ppm}$. Mixture1: It spread with high concentration at 2 L/600 liters water.

Mixture1: It spread with (low+ high concentrations) at (1.0ppm + 2L / 600liters water).

Mixture2: It spread with low concentration at 1.0 ppm.

Mixture2: It spread with high concentration at 2 liter/600 liter water.

Mixture2: It spread with (low + high concentrations) at (1.0ppm + 2L / 600 liters water).

Pepton: It spread with low concentration at 1000 ppm.

1- Pepton: It spread with high concentration with 2 $\mathrm{g} / \mathrm{L}$ concentration

2- Control (sprayed with water).
All treatments sprayed three times (in the mid of March; April and May) in both seasons. These experiment studied the efficiency of referred bioenzymatic compounds on tree fruiting; fruit quality; chemical analysis and genetic relate on [SDS- PAGE electrophoresis and two enzyme systems \{polyphenol-oxidase (PPO) and peroxidase\} were applied. The following measurements were carried out:-

\section{1) Tree fruiting:}

a- fruit number/tree: It was calculated at the end of May month.

b- Fruit yield/tree: At harvest time in both seasons the yield of selected trees were determined as $\mathrm{kg} /$ tree for all treatments.

2) Fruit quality:

Fruit measurements were made on 15 harvested fruits and included fruit weight, size, length, diameter, firmness (fruit without rind) using pressure tester with 1/4 'inch plunger (CataltricGeneratot, Inc. Norfolk, VA. USA), T.S.S, (Total Soluble Solids) A.O.A.C, 1975, Acidity, T.S.S / acidity, color lightness ( $\left.\mathrm{L}^{*}\right)$; Fruit (rind) color lightness were quantified at stimulus colormetery data $\left(\mathrm{L}^{*}\right)$ using Hunter Chroma meter model DP- 9000, color was represented by (whiteness/ darkness, ranged from 0 to 100 , while 100 being the lightest) Me Guire, 1992) and fruit color (CI): fruit color was quantified at tri stimulus colormetery $(\mathrm{L}, \mathrm{a}, \mathrm{b})$ using Hunter Chroma meter model DP- 9000,color was represented L (lightness), a (green - red) and b (blue yellow) scale, (Me Guire, 1992). The following equation was used to determine color index, Salvador etal., 1989).

$$
C I=1000 X \frac{a}{L b}
$$

3) Chlorophyll content in leaves:-At the end of the growing season, chlorophyll content was recorded using a Spd 502 chlorophyll meter as chlorophyll reading (Yadava 1986).

\section{4) Chemical analysis:}

It was included that leaf content of total phenols, total indols and total protein. Samples were taken for various measurements during late August in both seasons. Total phenols, total indols for all treatments Cplorimetrical analysis according to (A.O.A.C, 1975).

\section{Statistical analysis:}

A1I data were analyzed as factorial completely Randomized Design in factorial arrangement with three replications as described by Snedecor and Cochran (1990). The differences between means were differentiated using Duncan multiple range test Duncan (1955).

5) Genetic study:

A. Protein banding pattern in leaves:

- Protein extraction: 
Samples of leaves were taken from Anna apple cultivar and treated with different plant extracts by spread in one season. Total soluble protein were extracted by grounding 0.25 gof each sample in 0.9 $\mathrm{ml}$ extraction buffer $(10 \mathrm{ml} 0.5$ Mtris PH $6.8,16 \mathrm{ml}$ $10 \%$ SDS, $30 \mathrm{ml}$ D.W) with shaking thoroughly. The extracts were transferred to Eppendr of tubes and centrifuged for $10 \mathrm{~min}$ at $1000 \mathrm{rpm}$ under cooling. Supernatant were transferred by fresh tubes and used for SDS - PAGE analysis and extraction of isozymes was used as described by Janathan and Weeden, (1990).

- Protein related index:

Fractionation electrophoresis was performed under identical conditions on sodium dedocylsulphate polyacrylamide gel (SDS - PAGE) $(12 \% \mathrm{w} / \mathrm{v})$ vertical slab using BIORAD Techware $1.5 \mathrm{~mm}$ according to the method of Lammli (1970) as modified by Studier (1973). The molecular weights of proteins were estimated relative to maker, a wide range molecular weight protein (Fermentas com.).

B. Isozymes electrophoresis:

Native - polacryiamide gel electropresis (Native (PAGE) was performed in $12 \%$ (w/v) slab gel (Davis, 1964). The gel was stained after run according to Tankseley and Rick (1980) for poly phenyloxidase (ppo) isozymes and Grahan et al., (1964) for peroxidase isozymes. The staining gel was incubated at $37{ }^{\circ} \mathrm{c}$ in dark for complete staining after adding the appropriate substrates and staining solutions

\section{- Gel documentation:}

Gels were photographed scanned, analyzed using Gel Doc Vilberlourmat system to capture the image and to calculate band intensities.

\section{Results and Discussion}

1- Tree fruiting:

1-a- Fruit number per tree:
The performance of the studied treatment in the Table (1) indicated that mixture 2 (low + high) concentrations and pepton treatments gave the best significant fruit number per tree in the two seasons. Meanwhile, mixture 2 only was increased in the first season than the second season. In this respect, Crisosto etal., (1992) recorded that the influence of polyamines in increasing fruit set has been observed in apple and pear particularly"Comice" pear. Putrescince enhanced pollen tube ovule penetration and delayed ovule senescence without affecting flower ethylene production. In addition, Fayek etal., (2011) referred to that amino acids foliar spray applied twice during bud burst and full bloom stages at one $\mathrm{g} / \mathrm{L}$ on Le-Conte pear trees induced the highest significant initial and final fruit set percentages. Parallel results were attained by Yehia etal., (2009) illustrated that spraying anti-stress (polypeptide enzymes $15 \%$ ) at $0.66 \%$ at bud swelling, full bloom and two weeks after petal fall and the first of July on "Le-Conte" pear trees induced the highest significant fruit set compared with control. Also, Mouco etal., (2009) mentioned that increasing amino acid spraying rates enhanced the number of fruits per Mango plant.

\section{1-b- Yield per tree:-}

Data in Table (1) demonstrate that mixture 2 (low + high) concentration; Pepton and mixture ${ }_{1}$ induced the highest significant yield per tree in the two seasons. Whereas, Mixture 2 only was higher significant yield in the second season than the first season. In this regard, Yehia etal., (2009) stated that, foliar spray application of Anti-stress (polypeptide enzymes $15 \%$ ) at $0.66 \%$ at bud swelling, full bloom and two weeks after petal fall and the first of July on Le-Conte pear trees induced the highest fruit number pear tree. Similarly, Fayek etal., (2011) found that the amino acids foliar sprays applied twice during bud burst and full bloom stages at one $\mathrm{g} / \mathrm{L}$ on LeConte pear trees produced the highest significant yield.

Table 1. Effect of treatments on fruit number and yield per tree on Anna apple cultivar in 2013 and 2014 seasons.

\begin{tabular}{lllll}
\hline \multirow{2}{*}{ Treatments } & \multicolumn{3}{c}{ Fruit number /tree } & Yield(Kg)/ tree \\
\cline { 2 - 5 } & 2013 & 2014 & 2013 & 2014 \\
\hline Mixture $_{1} *$ & $122.67 \mathrm{C}$ & $123.33 \mathrm{CD}$ & $23.80 \mathrm{~A}$ & $22.48 \mathrm{~A}$ \\
Mixture $_{1} * *$ & $80.33 \mathrm{E}$ & $107.33 \mathrm{EF}$ & $10.95 \mathrm{D}$ & $16.23 \mathrm{BC}$ \\
Mixture $_{1} * * *$ & $93.33 \mathrm{D}$ & $125.67 \mathrm{C}$ & $14.91 \mathrm{C}$ & $18.32 \mathrm{~B}$ \\
Mixture $_{2}$ & $158.00 \mathrm{~A}$ & $151.00 \mathrm{~B}$ & $21.54 \mathrm{AB}$ & $23.96 \mathrm{~A}$ \\
Mixture $_{2} * *$ & $122.33 \mathrm{C}$ & $114.33 \mathrm{DE}$ & $15.36 \mathrm{C}$ & $17.25 \mathrm{BC}$ \\
Mixture $_{2} * * *$ & $154.00 \mathrm{~A}$ & $165.33 \mathrm{~A}$ & $22.45 \mathrm{~A}$ & $23.70 \mathrm{~A}$ \\
Pepton $^{* *}$ & $159.67 \mathrm{~A}$ & $176.00 \mathrm{~A}$ & $23.09 \mathrm{~A}$ & $25.12 \mathrm{~A}$ \\
Pepton** & $137.33 \mathrm{~B}$ & $153.33 \mathrm{~B}$ & $18.57 \mathrm{~B}$ & $25.83 \mathrm{~A}$ \\
\hline Control & $116.67 \mathrm{C}$ & $102.00 \mathrm{~F}$ & $13.29 \mathrm{C}$ & $14.23 \mathrm{C}$ \\
\hline
\end{tabular}

Mean in each column followed by the same letter (s) are not significantly different at 5\%.

Mixture1= Biolab ; Mixture2= Anti-stress

*low concentration $=1 \mathrm{ppm} \quad * *$ high concentration=2L/600 liter water

$* * *$ Low + high $=\{1 \mathrm{ppm}+2 \mathrm{~L} / 600$ liter water $\}$ concentrations. 


\section{2 - Fruit quality:}

Data of physical and chemical characteristics on Anna apple fruits as affected by bio-compounds spraying were arranged in Table (2) and (3)

\section{2-a- Fruit weight:}

Data in table (2) evident that mixture ${ }_{1}$ gave the highest significant weight in the two seasons respectively. The control treatment had the lowest significant value.

\section{2 -b- Fruit size:}

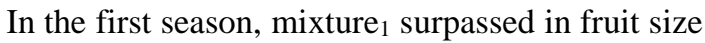
than the other treatments. But,in the second season $\operatorname{mixture}_{2}($ low+ high ) concentrations; mixture 2 ; pepton and the control treatments increased fruit size than the other treatments in Table (2).

2 -c- Fruit diameter:

Foliar spray with bio-compounds treatments produced higher fruit diameter with different arrangement than the control in the two seasons.

\section{2-d- Fruit length:}

Significant changes were reported between all treatments arrangement under study from season to another.

Table 2. Effect of treatments on some physical and chemical properties at fruit maturity on Anna apple cultivar in 2013 and 2014 seasons.

\begin{tabular}{|c|c|c|c|c|c|c|c|c|}
\hline Treatments & $\begin{array}{l}\text { Fruit } \\
\text { weight } \\
\text { (g.) } \\
\end{array}$ & $\begin{array}{l}\text { Fruit size } \\
\qquad\left(\mathrm{cm}^{3}\right)\end{array}$ & $\begin{array}{c}\text { Fruit } \\
\text { diameter } \\
(\mathrm{cm})\end{array}$ & $\begin{array}{c}\mathrm{F} . \\
\text { length } \\
(\mathrm{cm})\end{array}$ & $\begin{array}{c}\mathrm{F} . \\
\text { firmness }\end{array}$ & $\begin{array}{l}\text { TSS } \\
(\%)\end{array}$ & $\begin{array}{c}\text { Acidity } \\
(\%)\end{array}$ & $\begin{array}{c}\text { TSS/acid } \\
\text { ratio }\end{array}$ \\
\hline & \multicolumn{8}{|c|}{2013 season } \\
\hline Mixture $_{1} *$ & $194.1 \mathrm{~A}$ & $166.6 \mathrm{~A}$ & $6.50 \mathrm{AB}$ & $7.37 \mathrm{AB}$ & 14.29B & $10.50 \mathrm{C}$ & $0.50 \mathrm{D}$ & $21.00 \mathrm{~A}$ \\
\hline Mixture $_{1} * *$ & $136.8 \mathrm{C}$ & $125.1 \mathrm{C}$ & $6.53 \mathrm{~A}$ & $6.87 \mathrm{~B}$ & $15.37 \mathrm{~A}$ & $10.00 \mathrm{C}$ & $0.59 \mathrm{D}$ & $17.05 \mathrm{C}$ \\
\hline Mixture $_{1} * * *$ & $159.7 \mathrm{~B}$ & 147.1B & $6.53 \mathrm{~A}$ & $7.73 \mathrm{~A}$ & $15.29 \mathrm{~A}$ & $10.63 \mathrm{C}$ & $0.60 \mathrm{D}$ & $17.82 \mathrm{C}$ \\
\hline Mixture $_{2} *$ & $136.8 \mathrm{C}$ & 118.3CD & $6.20 \mathrm{~B}$ & $7.10 \mathrm{~B}$ & $7.61 \mathrm{D}$ & $10.83 \mathrm{C}$ & $0.57 \mathrm{D}$ & 19.10B \\
\hline Mixture $2 * *^{*}$ & $137.2 \mathrm{C}$ & $120.7 \mathrm{C}$ & $6.50 \mathrm{~B}$ & $7.20 \mathrm{~B}$ & $10.08 \mathrm{C}$ & $10.50 \mathrm{C}$ & $0.53 \mathrm{D}$ & 19.81B \\
\hline Mixture $_{2} * * *$ & 146.1BC & $115.8 \mathrm{CD}$ & $5.90 \mathrm{C}$ & $6.87 \mathrm{~B}$ & $15.22 \mathrm{~A}$ & $13.33 \mathrm{~A}$ & $0.80 \mathrm{C}$ & $16.74 \mathrm{C}$ \\
\hline Pepton * & 149.0C & $90.6 \mathrm{E}$ & $6.67 \mathrm{~A}$ & $6.83 \mathrm{~B}$ & $10.41 \mathrm{C}$ & $10.33 \mathrm{C}$ & $0.61 \mathrm{D}$ & $17.03 \mathrm{C}$ \\
\hline Pepton ** & $134.2 \mathrm{C}$ & 141.7B & $3.37 \mathrm{~B}$ & $6.77 \mathrm{~B}$ & $9.67 \mathrm{C}$ & $12.33 \mathrm{~B}$ & $0.98 \mathrm{~B}$ & $12.63 \mathrm{D}$ \\
\hline Control & 112.7D & $102.7 \mathrm{E}$ & $4.97 \mathrm{C}$ & $5.00 \mathrm{C}$ & $14.98 \mathrm{AB}$ & $7.30 \mathrm{D}$ & $1.20 \mathrm{~A}$ & $6.08 \mathrm{E}$ \\
\hline \multicolumn{9}{|c|}{2014 season } \\
\hline Mixture1 * & $177.1 \mathrm{~A}$ & 197.0B & $6.73 \mathrm{BC}$ & $7.17 \mathrm{C}$ & $3.93 \mathrm{C}$ & $10.50 \mathrm{C}$ & $0.74 \mathrm{CD}$ & $14.25 \mathrm{BC}$ \\
\hline Mixture1 ** & 152.0CD & 193.0B & 6.50CD & $7.10 \mathrm{C}$ & $3.97 \mathrm{C}$ & $10.53 \mathrm{C}$ & $0.72 \mathrm{CD}$ & $14.63 \mathrm{AC}$ \\
\hline Mixture1 $* * *$ & $145.4 \mathrm{CD}$ & 190.0B & $6.70 \mathrm{BC}$ & $7.70 \mathrm{AB}$ & $4.10 \mathrm{C}$ & $10.33 \mathrm{C}$ & $0.60 \mathrm{D}$ & $17.22 \mathrm{~A}$ \\
\hline Mixture2 * & 157.7BC & 201.8AB & $6.80 \mathrm{BC}$ & 7.30BC & $3.33 \mathrm{D}$ & $10.07 \mathrm{C}$ & $0.65 \mathrm{D}$ & $15.41 \mathrm{AC}$ \\
\hline Mixture $_{2} * *$ & $150.6 \mathrm{CD}$ & $175.9 \mathrm{C}$ & $6.93 \mathrm{AB}$ & 7.43BC & $4.80 \mathrm{~B}$ & $10.90 \mathrm{C}$ & $0.80 \mathrm{D}$ & $13.68 \mathrm{C}$ \\
\hline $\operatorname{Mixture}_{2} * * *$ & $141.8 \mathrm{D}$ & $210.8 \mathrm{~A}$ & $6.77 \mathrm{BC}$ & $7.20 \mathrm{C}$ & $5.00 \mathrm{~B}$ & 13.60B & 0.94B & $14.42 \mathrm{C}$ \\
\hline Pepton * & 141.7D & 201.7AB & 6.50CD & $7.30 \mathrm{C}$ & $5.20 \mathrm{~B}$ & $11.00 \mathrm{C}$ & $0.64 \mathrm{D}$ & 17.19A \\
\hline Pepton ** & 167.7AB & 192.6B & $7.17 \mathrm{~A}$ & $7.93 \mathrm{~A}$ & $3.73 \mathrm{D}$ & $10.03 \mathrm{~A}$ & $0.90 \mathrm{C}$ & $16.77 \mathrm{~B}$ \\
\hline Control & 139.7D & 201.7B & $6.23 \mathrm{D}$ & $7.47 \mathrm{BC}$ & $5.83 \mathrm{~A}$ & $7.67 \mathrm{D}$ & $1.41 \mathrm{~A}$ & $5.45 \mathrm{D}$ \\
\hline
\end{tabular}

Mean in each column followed by the same letter (s) are not significantly different at $5 \%$.

Mixture1= Biolab ; Mixture2= Anti-stress

$*$ low concentration $=1 \mathrm{ppm} \quad * *$ high concentration $=2 \mathrm{~L} / 600$ liter water $\quad * * *$ low + high $=\{1 \mathrm{ppm}+2 \mathrm{~L} / 600$ liter water $\}$ concentrations

\section{2 -E- Fruit firmness:}

Mixture $_{1}$ (high concentration); mixture ${ }_{1}$ (low + high) concentration and mixture 2 (low + high) concentration was significantly increased fruit firmness in the first season. Meanwhile, control treatment gave the highest value in the second season.

2 -F- Total soluble solids (T.S.S):

Mixture $_{2}($ low + high) concentration and pepton high concentration were the best values of T.S.S with different arrangement from season to another. But, control had the lowest values in the two seasons.

2-g- Acidity (\%):

Acidity percentage was decrease significantly with foliar spray with bio-compounds treatments. But, control had the highest values of acidity $\%$ in both seasons.

\section{2-h- T.S.S / acidity ratio:}

Foliar spray with bio-compounds treatments had significantly increases T.S.S / acid with different arrangement from season to another compared to the control that gave the lowest significant values of T.S.S / acid ratio.

\section{2 -i- Fruit color:}

Data in table (3) cleared that spraying with mixture ${ }_{2}$ (low + high) concentration; mixture ${ }_{1}$ high concentration and mixture 2 had more pronounced positive effect on fruit color in the two seasons.

\section{2 -j- color index:}

Pepton high concentration was the best color index in the two seasons. On the other hand, control had the lowest value in the two seasons.

These results are in harmony with El-razek and Saeleh etal.,( 2012) who found that foliar and /or soil application of amino acid ( in form of pept on as a commercial product) had positive effect on 
productivity and fruit quality of "Florida Prince" peach. Also, In addition, a major determinate of citrus fruit quality, accumulates early in fruit development and declines towards maturation results in amino acid biosynthesis Degu etal., (2011). Moreover, Yehia etal., (2009) noticed that foliar sprayed application of $0.66 \%$ Anti-stress at bud swelling, full bloom and two weeks after petal fall and first of July on Le-Conte pear trees induced the highest significant fruit weight. Fayek etal., (2011) noticed that foliar sprayed amino acids at bud burst and full bloom stages at one $\mathrm{g} / \mathrm{L}$ on Le-conte trees produced the highest significant fruit weight. Bezold etal., (2003) declared that the plant systems that are responsible for dividing tissues exert high levels of polyamines and activities of their biosynthetic enzymes. Meanwhile, Mouco etal., (2009) referred that amino acid sprays lightly delayed the evaluation of skin huminosity and degree of Hue of pulp, but the differences were not visually identified on Mango.

Table 3. Effect of treatments on color properties at fruit maturity on Anna apple cultivar in 2013 and 2014 seasons.

\begin{tabular}{|c|c|c|c|c|}
\hline \multirow{2}{*}{ Treatments } & \multicolumn{2}{|l|}{ Fruit color } & \multicolumn{2}{|l|}{ Color index } \\
\hline & 2013 season & 2014 season & 2013season & 2014 season \\
\hline Mixture $_{1} *$ & $65.92 \mathrm{C}$ & $64.37 \mathrm{C}$ & $1.29 \mathrm{BC}$ & $1.52 \mathrm{~B}$ \\
\hline Mixture $_{1} * *$ & $67.64 \mathrm{~A}$ & $65.92 B$ & $0.68 \mathrm{CD}$ & $0.44 \mathrm{CD}$ \\
\hline Mixture $_{1} * * *$ & $61.51 \mathrm{D}$ & $61.03 \mathrm{E}$ & $2.04 \mathrm{AB}$ & $1.51 \mathrm{~B}$ \\
\hline Mixture $_{2} *$ & $68.14 \mathrm{~A}$ & $65.90 \mathrm{~B}$ & $0.93 \mathrm{CD}$ & $0.66 \mathrm{CD}$ \\
\hline Mixture $_{2} * *$ & $66.40 \mathrm{~B}$ & $65.22 \mathrm{C}$ & $1.07 \mathrm{C}$ & $1.11 \mathrm{BC}$ \\
\hline Mixture $_{2} * * *$ & $68.33 \mathrm{~A}$ & $68.31 \mathrm{~A}$ & $0.90 \mathrm{CD}$ & $0.60 \mathrm{CD}$ \\
\hline Pepton * & $64.66 \mathrm{C}$ & $61.25 \mathrm{E}$ & $1.93 \mathrm{~B}$ & $1.46 \mathrm{~B}$ \\
\hline Pepton ** & $63.97 \mathrm{C}$ & $62.22 \mathrm{D}$ & $2.79 \mathrm{~A}$ & $2.47 \mathrm{~A}$ \\
\hline Control & $62.26 \mathrm{C}$ & $61.25 \mathrm{E}$ & $0.14 \mathrm{D}$ & $0.15 \mathrm{D}$ \\
\hline
\end{tabular}

Mean in each column followed by the same letter (s) are not significantly different at $5 \%$.

Mixture1= Biolab ; Mixture2= Anti-stress

$*$ low concentration $=1 \mathrm{ppm} \quad * *$ high concentration $=2 \mathrm{~L} / 600$ liter water $* * *$ low + high $=\{1 \mathrm{ppm}+2 \mathrm{~L} / 600$ liter water $\}$ concentrations

\section{3-3- chlorophyll content in leaves:-}

Data in Table (4) show that there are significant differences in the values of chlorophyllcontent in leaves. Mixture ${ }_{1}\left(\right.$ low + high) con.and mixture ${ }_{2}$ high con.had significant increases in two seasons than the other treatments which were different arrangement from season to another. Meanwhile, the lowest chlorophyll content was with the control treatment. In this respect, El-Razek and Saieh (2012) mentioned that chlorophyll content had a positive effect with amino acids (in form of pepton as a commercial product) foliar and/or soil application of Florida Prince peach. Also, Refaat and Naguib (1998) reported that application of all amino acids (alanine, cytosine, guanine and L-tyrosine) increased the total carbohydrates percentage in peppermint leaves.

Table 4. Effect of treatments on chlorophyll percentage in leaves on Anna apple cultivar in 2013 and 2014 seasons.

\begin{tabular}{lcc}
\hline \multirow{2}{*}{ Treatments } & \multicolumn{2}{c}{ Total chlorophyll } \\
\cline { 2 - 3 } & 2013 season & 2014 season \\
\hline Mixture $_{1} *$ & $45.07 \mathrm{CD}$ & $48.00 \mathrm{~A}$ \\
Mixture $_{1} * *$ & $48.90 \mathrm{~A}$ & $44.30 \mathrm{CD}$ \\
Mixture $_{1} * *$ & $48.77 \mathrm{~A}$ & $46.03 \mathrm{AC}$ \\
Mixture $_{2} *$ & $48.57 \mathrm{~A}$ & $45.43 \mathrm{BC}$ \\
Mixture $_{2} * *$ & $47.27 \mathrm{AB}$ & $46.53 \mathrm{AB}$ \\
Mixture $_{2} * *$ & $44.07 \mathrm{D}$ & $42.90 \mathrm{D}$ \\
Pepton $^{*}$ & $46.53 \mathrm{BC}$ & $48.00 \mathrm{~A}$ \\
Pepton $* *$ & $44.43 \mathrm{D}$ & $47.70 \mathrm{~A}$ \\
\hline Control & & $38.63 \mathrm{E}$ \\
\hline
\end{tabular}

Mean in each column followed by the same letter (s) are not significantly different at $5 \%$.

Mixture1= Biolab ; $\quad$ Mixture2= Anti-stress

$*$ low concentration $=1 \mathrm{ppm} * *$ high concentration $=2 \mathrm{~L} / 600$ liter water $* * *$ low + high $=\{1 \mathrm{ppm}+2 \mathrm{~L} / 600$ liter water $\}$ concentrations

The pormotive affected of the amino acids on total carbohydrates content may be due to their important role on the biosynthesis of chlorophyll molecules which in turn affected carbohydrates content.

3-4- chemical analysis:
Data in Table (5) cleared that treatments performance on total phenols; total indoles and total protein in two seasons under study.

\section{3-4-1- total phenols:}


The highest significant total phenols with control treatment in the two seasons respectively. The lowest values with mixture ${ }_{1} ;$ mixture $_{2} ;$ mixture $_{2}($ low + high $)$ concentrations and pepton high concentration treatments in the two seasons under study.

\section{3-4-2- total indoles:-}

Total indoles were the highest with pepton in the two seasons respectively. The lowest values with mixture $_{1}$ (low + high) concentrations and control treatments in the two seasons under study.

\section{3-4-3- total protein:-}

With mixture ${ }_{2}$ total protein had the highest values in the two seasons of study. The lowest values were recorded with mixture ${ }_{1}$ high concentration in the two seasons respectively. In this respect, Degu et al., (2011) mentioned that treated citrus with amino acid slightly inducing its protein in fruit. Also, Soad et al., (2010) found that total indoles levels were decreased by the increase in peptone levels.

Table 5. Effect of treatments on total phenols; total indoles and total protein of Anna apple cultivar in 2013 and 2014 seasons.

\begin{tabular}{lllllll}
\hline \multirow{2}{*}{ Treatments } & total phenols & \multicolumn{3}{c}{ total indoles } & \multicolumn{3}{c}{ total protein } \\
& 2013 & 2014 & 2013 & 2014 & 2013 & 2014 \\
\hline Mixture $_{1} *$ & $0.79 \mathrm{D}$ & $0.72 \mathrm{E}$ & $2.87 \mathrm{C}$ & $2.81 \mathrm{D}$ & $13.01 \mathrm{~B}$ & $13.11 \mathrm{~B}$ \\
Mixture $_{1} * *$ & $0.82 \mathrm{~B}$ & $0.83 \mathrm{AB}$ & $2.85 \mathrm{C}$ & $2.89 \mathrm{C}$ & $9.29 \mathrm{~F}$ & $9.22 \mathrm{~F}$ \\
Mixture $_{1} * *$ & $0.81 \mathrm{C}$ & $0.81 \mathrm{BC}$ & $2.57 \mathrm{~F}$ & $2.62 \mathrm{E}$ & $10.22 \mathrm{D}$ & $10.30 \mathrm{D}$ \\
Mixture $_{2} *$ & $0.78 \mathrm{D}$ & $0.77 \mathrm{DE}$ & $2.60 \mathrm{E}$ & $2.53 \mathrm{~F}$ & $11.07 \mathrm{C}$ & $11.10 \mathrm{C}$ \\
Mixture $_{2} * *$ & $0.81 \mathrm{C}$ & $0.82 \mathrm{~A}-\mathrm{E}$ & $2.73 \mathrm{D}$ & $2.77 \mathrm{D}$ & $14.18 \mathrm{~A}$ & $14.22 \mathrm{~A}$ \\
Mixture $_{2} * *$ & $0.78 \mathrm{D}$ & $0.77 \mathrm{DE}$ & $2.72 \mathrm{D}$ & $2.74 \mathrm{D}$ & $8.38 \mathrm{I}$ & $8.36 \mathrm{I}$ \\
Pepton $^{*}$ & $0.80 \mathrm{C}$ & $0.80 \mathrm{C}$ & $3.25 \mathrm{~A}$ & $3.27 \mathrm{~A}$ & $8.65 \mathrm{G}$ & $8.65 \mathrm{G}$ \\
Pepton $* *$ & $0.77 \mathrm{D}$ & $0.77 \mathrm{DE}$ & $3.03 \mathrm{~B}$ & $3.05 \mathrm{~B}$ & $8.56 \mathrm{H}$ & $8.51 \mathrm{H}$ \\
Control & $0.84 \mathrm{~A}$ & $0.84 \mathrm{~A}$ & $2.60 \mathrm{E}$ & $2.51 \mathrm{~F}$ & $10.16 \mathrm{E}$ & $10.15 \mathrm{E}$ \\
\hline
\end{tabular}

Mean in each column followed by the same letter (s) are not significantly different at $5 \%$.

Mixture1= Biolab Mixture2= Anti-stress *low concentration $=1 \mathrm{ppm}$

$* *$ high concentration $=2 \mathrm{~L} / 600$ liter water $\quad * * *$ low + high $=\{1 \mathrm{ppm}+2 \mathrm{~L} / 600$ liter water $\}$ concentrations

\section{3-5- Genetic study:}

\section{3-5-1-Protein banding pattern in leaves:}

The electrophoretic banding pattern of proteins extracted from leaves of nine treatments on Anna Apple were show in figure (1) and their desitrometric analysis were illustrated in Table (6), the presence and absence of bands were associated with $(+)$ and $(-$ ) respectively.

Results of leaves SDS-PAGE revealed a total number of 44 protein bands with molecular weight (MW) ranging from about 185.364 to $15 \mathrm{KDa}$. A total of 24 common bands (monomorphic bands) were detected while, the remaining twenty bands were polymorphic with $45.45 \%$ polymorphism. This variation was found between present or absent bands with different treatments may be due to the differences between improving fruit quality of Anna apple cultivar. In this respect, Deguet al., (2011)mentioned that treated citrus with amino acid slightly inducing its fruit protein. Rasmia(2013) mentioned that treatments with either proline or phenylalanine might play an important role in protein synthesis. Also, amino acids have traditionally been considered as precursors and constituents of protein (Sabry etal., 2009).

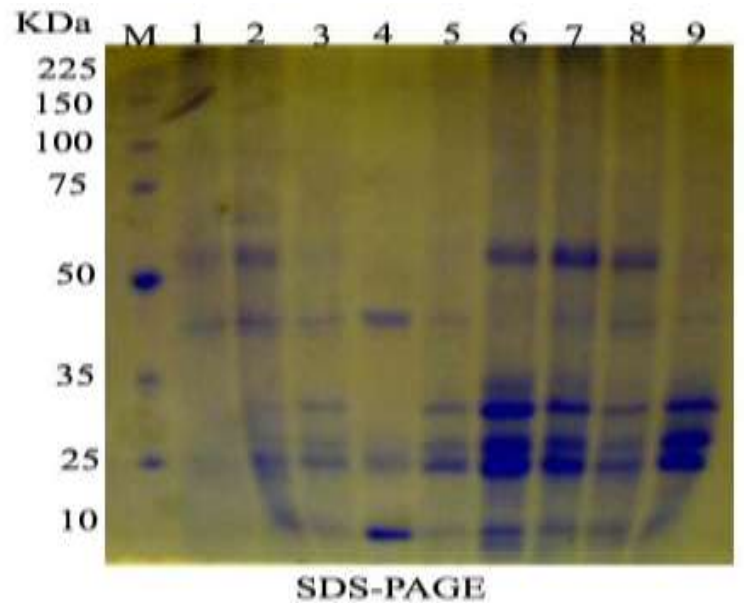

Figure (1):- SDS- Protein banding patterns of leaf proteins for the eight "Anna" apple treatments in compared with control.

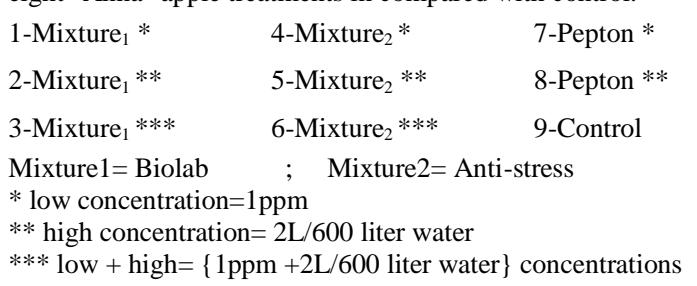


Table 6. Protein banding patterns of improving fruit qualities of Apple trees "Anna cv." grown on Malus rootstock by bio-enzymatic compounds.

\begin{tabular}{|c|c|c|c|c|c|c|c|c|c|c|}
\hline 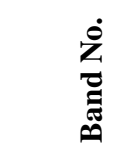 & $\begin{array}{l}\dot{z} \\
\dot{\Sigma}\end{array}$ & & 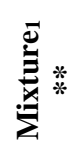 & 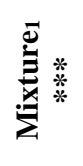 & 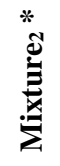 & & 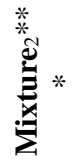 & ڤే & 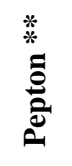 & 홍 \\
\hline 1 & 185.364 & + & + & - & - & - & - & - & - & - \\
\hline 2 & 168.474 & + & - & - & - & - & - & - & - & - \\
\hline 3 & 165.485 & - & + & - & - & - & - & - & - & - \\
\hline 4 & 75.695 & - & + & - & - & - & - & - & - & - \\
\hline 5 & 62.158 & - & - & - & - & + & - & + & - & - \\
\hline 6 & 61.604 & - & + & - & - & - & - & - & - & - \\
\hline 7 & 59.971 & + & - & - & - & - & - & - & - & - \\
\hline 8 & 59.436 & - & - & - & - & - & + & - & - & - \\
\hline 9 & 58.381 & - & - & - & - & - & - & + & + & - \\
\hline 10 & 43.313 & - & - & - & + & - & - & - & - & - \\
\hline 11 & 42.544 & - & - & - & - & + & - & - & - & - \\
\hline 12 & 42.165 & - & - & - & + & - & - & - & - & - \\
\hline 13 & 41.789 & - & + & + & - & - & - & + & - & - \\
\hline 14 & 41.416 & - & - & - & - & - & - & - & + & + \\
\hline 15 & 41.047 & + & - & - & - & - & - & - & - & - \\
\hline 16 & 39.721 & - & - & - & - & - & - & - & + & - \\
\hline 17 & 39.367 & - & - & - & - & - & - & - & - & + \\
\hline 18 & 29.381 & - & - & - & - & - & + & - & - & - \\
\hline 19 & 25.611 & - & - & - & - & - & - & + & - & + \\
\hline 20 & 25.383 & - & + & + & - & - & - & - & + & - \\
\hline 21 & 25.156 & - & - & - & - & - & + & - & - & + \\
\hline 22 & 24.932 & - & - & - & - & - & - & + & - & - \\
\hline 23 & 23.698 & - & - & - & - & - & + & - & - & - \\
\hline 24 & 21.157 & - & + & - & - & - & + & - & - & - \\
\hline 25 & 20.658 & - & - & - & - & - & - & + & - & - \\
\hline 26 & 20.473 & - & - & - & - & - & - & - & + & + \\
\hline 27 & 20.291 & - & - & + & - & - & - & + & - & - \\
\hline 28 & 20.110 & - & - & - & - & + & - & - & - & - \\
\hline 29 & 19.931 & - & - & - & - & - & - & + & - & + \\
\hline 30 & 18.774 & - & - & - & - & - & - & + & - & - \\
\hline 31 & 18.442 & - & - & + & - & - & - & - & - & - \\
\hline 32 & 18.278 & - & + & - & - & - & - & - & + & + \\
\hline 33 & 18.115 & + & - & - & - & + & - & - & - & - \\
\hline 34 & 18.007 & - & - & - & + & - & + & - & - & - \\
\hline 35 & 17.846 & - & - & - & - & - & - & + & - & + \\
\hline 36 & 17.530 & - & - & - & - & + & - & - & - & - \\
\hline 37 & 16.812 & - & - & - & - & - & + & - & - & - \\
\hline 38 & 13.201 & - & + & - & - & - & - & - & - & - \\
\hline 39 & 12.623 & - & - & - & - & - & - & + & - & - \\
\hline 40 & 12.436 & - & - & - & - & - & + & - & + & - \\
\hline 41 & 12.325 & - & - & - & + & - & - & - & - & - \\
\hline 42 & 12.215 & - & - & + & - & + & - & - & - & - \\
\hline 43 & 11.891 & - & - & - & + & - & - & - & - & - \\
\hline \multirow[t]{2}{*}{44} & 11.610 & - & - & - & - & - & + & - & - & - \\
\hline & Total & 5 & 9 & 5 & 5 & 7 & 9 & 11 & 7 & 8 \\
\hline \multicolumn{11}{|c|}{ Mixture2= Anti-stress } \\
\hline \multicolumn{11}{|c|}{$\begin{array}{l}* \text { *low concentration }=1 \mathrm{ppm} \quad * * \text { high concentration }=2 \mathrm{~L} / 600 \text { liter water } \\
* * * \text { low }+ \text { high }=\{1 \mathrm{ppm}+2 \mathrm{~L} / 600 \text { liter } \text { water }\} \text { concentrations Polymorphic }=44 \text { bands }\end{array}$} \\
\hline
\end{tabular}




\section{3-5-1-Isozyme electrophoresis:}

Table (7) and figure (2) demonstrated poly phenol oxidase (PPO) banding patterns among examined fresh leaves of the eight treatments with some bio-enzymatic compounds from ( $t_{1}$ to $\left.t_{8}\right)$ and untreated of Anna apple cultivar.

Data presented in table (7) and figure (2) explains that, the total of four poly phenol oxidase (PPO) bands were present with differences in density of bands. In PPO1 was present with mixture ${ }_{1}$; mixture 2 high con.; mixture 2 (low +high) con.; pepton; pepton high con. and control. In $\mathrm{PPO}_{2}$ was present with mixture $_{2}$ high con.; pepton ;pepton high con. and control. In PPO 3 was present with all treatments under study.

Table 7. Endeogram analysis for leaf polyphenol oxidase isozyme banding patterns leaf for the eight Anna apple treatments in compared with control.

\begin{tabular}{|c|c|c|c|c|c|c|c|c|}
\hline Mixture $_{1} *$ & $\begin{array}{l}\text { Mixture }_{1} \\
* *\end{array}$ & $\begin{array}{l}\text { Mixture }_{1} \\
* * *\end{array}$ & Mixture $_{2} *$ & $\begin{array}{l}\text { Mixture }_{2} \\
* *\end{array}$ & $\begin{array}{l}\text { Mixture }_{2} \\
\text { * }^{2}\end{array}$ & $\begin{array}{l}\text { Pepton } \\
*\end{array}$ & $\begin{array}{l}\text { Pepton } \\
* *\end{array}$ & control \\
\hline - & & & & - & - & - & - & - \\
\hline & & & & - & & - & - & \\
\hline - & - & & - & - & - & - & & \\
\hline 二 & - & - & - & - & - & - & - & - \\
\hline
\end{tabular}

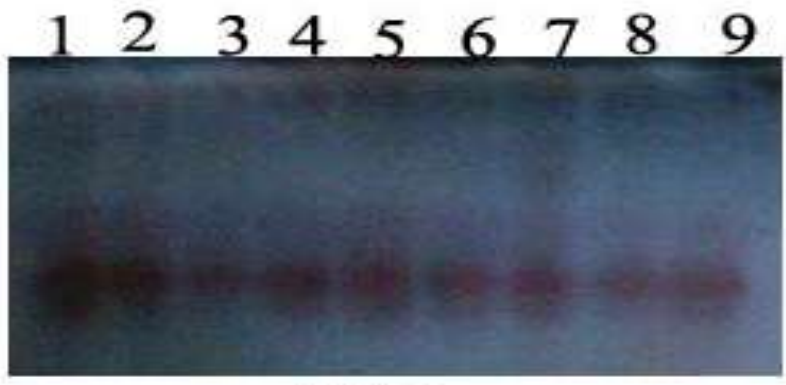

\section{PPO}

Figure (2):- Poly Phenol oxidase (PPO) isozyme banding patterns of leaf proteins for the eight "Anna" apple treatments in compared with control.
1 -Mixture ${ }_{1}^{*}$
$2-$ Mixture $_{1} * *$
3-Mixture $1 * *$
Mixture1 $=$ Biolab
*low concentration $=1 \mathrm{ppm}$
$* *$ high concentration $=2 \mathrm{~L} / 600$ liter water
$* * *$ low + high $=\{1 \mathrm{ppm}+2 \mathrm{~L} / 600$ liter water $\}$ concentrations

Table (8) and figure (3) demonstrated peroxidase banding patterns among examined fresh leaves of the eight treatments with some bio-enzymatic compounds from $\left(t_{1} t_{0} t_{8}\right)$ and untreated of Anna apple cultivar.

Data presented in table (8) and figure (3) explains that, the total of seven peroxidase (PX) bands were present with differences in density of bands. In $\mathrm{PX}_{1}$;
$\mathrm{PX}_{2} ; \mathrm{PX}_{3}$ and $\mathrm{PX}_{4}$ were present in all treatments under study. However, $\mathrm{PX}_{5}$ was present in all treatments except mixture 1 (low + high) con.; Mixture $_{2}$ (low +high) con. And pipton high con.; $\mathrm{PX}_{6}$ and $\mathrm{PX}_{7}$ were present in pepton and control only.

Table 8. Endeogram analysis for leaf peroxidase isozyme banding patterns leaf for the eightAnna apple treatments in compared with control.

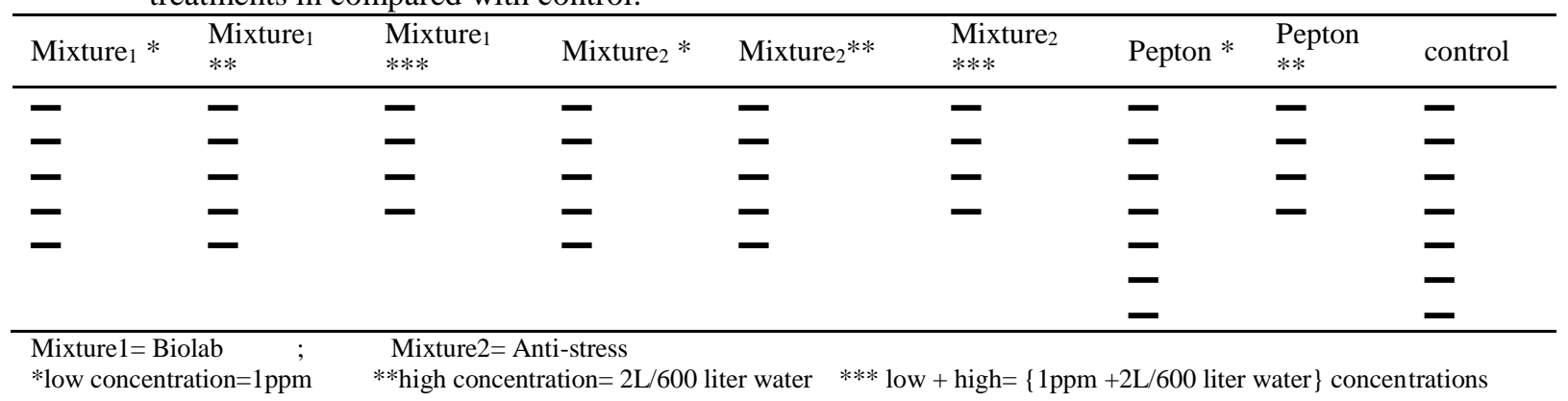




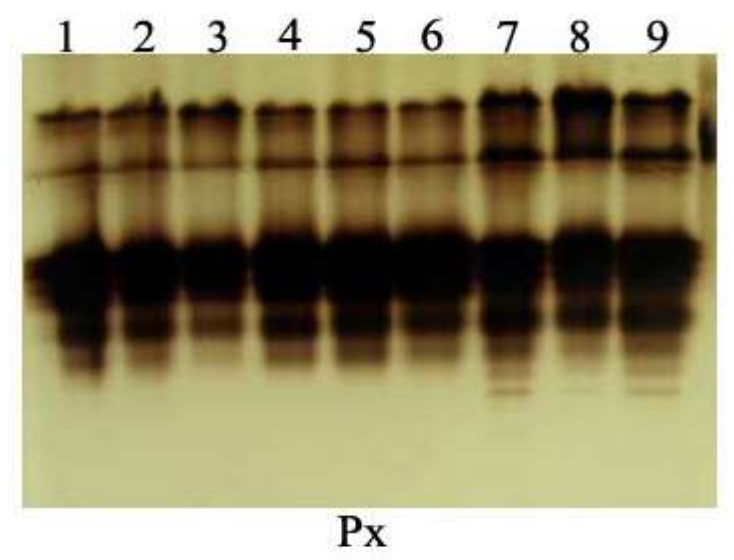

Figure (3):- Peroxidase (PX) isozyme banding patterns leaf for eight treatments of Anna apple cultivar in compared with control.

\begin{tabular}{|c|c|c|}
\hline 1 -Mixture $1 *$ & 4-Mixture ${ }_{2}^{*}$ & 7-Pepton * \\
\hline 2 -Mixture ${ }_{1} * *$ & 5 -Mixture $2 * *$ & 8-Pepton ** \\
\hline 3 -Mixture 1 *** & 6 -Mixture ${ }_{2} * * *$ & 9-Control \\
\hline Mixture1= Biolab & ; $\quad$ Mixtu & Mixture2= Anti-stress \\
\hline \multicolumn{3}{|l|}{ *low concentration } \\
\hline high concentrati & $2 \mathrm{~L} / 600$ liter $\mathrm{w}$ & \\
\hline
\end{tabular}

\section{Conclusion}

It can be recommended that spraying with bio compound are improving fruit quality of Anna apple cultivar.Mixture 2 \{low and high $\}$ with concentration $\{1.0 \mathrm{ppm}+2 \mathrm{~L} / 600$ liter water $\}$; Mixture1 with concentration $1 \mathrm{ppm}$ and pepton with concentration $1000 \mathrm{ppm}$ are improving yield and fruit quality.

\section{References}

Adams J. A. (1986). Nitrification and ammonification in acid forest litter and humus as affected by pepton and ammonium- $n$ amendment. Soil biology and Biochemistry 18, 1. 45-51

A.O.A.C, (1975): Official methods of analysis (15 ed) Association of Official Analysis chemists. Washington D.C.

Bezold, T. N.; Loy, J. B. and Minocha, S. C. (2003). Changes in the cellular content of polyamines in different tissues of seed and fruit of a normal and a hull-less seed variety of pumpkin during development. Plant Sci. 164, 743- 752.

Crisosto, C. H.; Lombard, P. B.; Richardson, D. G. and Tetley, R. (1992).Putrescence rxtends effective pollination period in "Comice" pear (PyrusCommunos L.) irrespective of postanthesisethylene levels. Sci. Hort., 49: 211- 221.

Davis, B. J. (1964): Disc electrophoresis, II Methods and application to human serum proteins. Am - N - Y - Acad. Sci. 121: 404 - 427.

Duncan, D. B. (1955): Multiple rang and multiple F. test. Biometries, 11:1 - 42.

Degu, A.; Hatew, B.; Nunes, A.; Shizeman, L.; Zur, N.; Katz, E.; Fernie A.R.; Blumwald, E. and Sadka, A. (2011). Inhibition of aconites in citrus results in a metabolic shift toward amino acid biosynthesis.Planta; 234 (3): 501 - 51363 ref.

El-Razek,E.A. and Saleh, M. M.S. (2012). Improve productivity and fruit quality of Florida Prince peach trees using foliar and soil application of amino acids. Middle east Jouranal of scienticResearch ; 12 (8): 1165-1172,35 ref.

Fayek, M. A.; Yehia, T. A.; El- Fakhrany, E. M. M.; and Farag, A. M. (2011).Effect of rining and amino acids application on improving fruiting of "Le-Conte" pear trees. Journal of Horticultural Science \& Ornamental plant 3 (1) : 1- 10.

Franco - Mora, O. K.; Tanabe, F. T. and Itai, A. (2005). Effect of putrescine application on fruit set Housui Japanese pear (PrunusPyrifoliaNakai). Sci. Hort. 104: $265-273$.

Goss, J. A.,(1973). Amino acids synthesis and metabolism physiology of plants and their cell. P. 202 Pergamon Press INC, New York, Toronto, Oxford, Sydney, Braunschwing.

Grahan. R.C.; Lundholm U. and Karnovsky M.J. (1964): Cytochemical demonstration of peroxidase activity with 3 - amino - g ethylcarbazole. J. Hisrochem. Cytochem. 13: 150-152.

Hass, D. (1975). Molecular biochemical and physiology fundamentals of metabolism and development. Plant Physiology 512 - 610 SpringVerlag, Berlin, Heidelberg, New york.

Jonathan, F.W. andWeeden, N.F. (1990): Visualization and interpretation of plant isozymes in plant Biology. D.E. Soltis and P.S. Soltis (eds). London chman and Hall, pp. 5-45.

Lammli, U.K. (1970). Cleavage of structural proteins during the assembly of the assembly of the head of bacteriophage Ty. Nature, 227: 680 - 685.

MeGuire, R.G. (1992): Reporting of objective color measurements. Hortscience, 27 (12): 1254- 1255.

Mohamed,S. M. and Khalil, M. M. (1992). Effect of tryptophan and arginine on growth and flowring of some winter annuals. Egypt J. Appl. Sci., 7 (10): 82- 93 .

Mouco, M. A. doc.; Lima M. A.C. de; Silva, A.L. da; Santos, S.C.A. dos and Rodrigues, F.M. (2009). Amino acids on mango yield anf fruit quality at submediosao Francisco Region, Brazil. ActaHorticulturae (820): 437- 442. 12 ref.

Rasmia, S.S. D. (2013). Improving growth of date palm plantlets grown under salt stress with yeast and amino acids applications. Annals Agricultural Science 58(2): 247- 256.

Refaat, A.M. and Naguib, N.Y. (1998). Peppermint yield and oil quality as affected by application of some amino acids. Bull. Fac. Agric. Univ. Cairo, 49: 89 -98.

Sabry, G.H.; MervatRizk, S. and Abd El-Wahab, M.A. (2009). Influence of effective microorganisms, seaweed extract and amino acids 
application on growth, yield and quality of Red Globe grapevines. J. Agri. Sci. Mansoura Univ., 34: 5901- 5921.

Saeid, I.A. and Kalil, M.A. (1992). Evaluation of some cultivars compared with "Anna" cultivar on two rootstocks. J. Agric. Sci. . Mansoura Univ., 17(12): 3900-3905.

Salvador, A.; CuquerelloJ.andManavervo P. (1989): New claminten cultivar responses to de greening physiological and technological aspects of gaseues and therminal treatment of fresh fruit and vegetative. Madrid 1989 Conference.

Silvaira, J.A.;Viegas, R.A.; da Rocha, I.M.; Moreira, A.C.; Moteira R.A. and Oliveira J.T. (2003).Proline accumulation and glutamine synthetase activity and increased by salt-induced proteolysis in cashew leaves. Journal of plant physiology 160, 115-123.

Snedecor, G. W. and Cochran W. G. (1990): Statistical Methods. 7th Ed. The Iowa state Univ., press ames. Iowa USA, P. 593.

Soad, M. I.; Lobn, S.T. and M.M. Farahat (2010). Influence of foliar application of pepton on growth, flowering and chemical composition of
Helichrysumbracteatum plants under different irrigation intervals. Ozean Journal of applied Sciences 3 (1).

Studier, F.W. (1973): Analysis of Bacteriophage T4 early RNAS and proteins of slab gei. J. Mol. Bio. 79:237-248

Tankesley, S. D. and Rick C. M. (1980): Genetic of Estrases in species of lycpersicon. Theor. Appl. Genet. 56: 209 - 219.

Valero,D.; Martinez - Romero, D. and Serrano, M. (2002). The role of polyamines in the improvement of the shelf life of fruit.Trends food Sci Tech., 13: 228- 234.

Yadova, Y. L. (1986): A rapid and non - destructive method to determine chlorophyll in intact leaves. Hort. Science. 12: 1449 - 1450.

Yehia, M. M.; Mohamed, S.Y.; Wesam, A. N. and Hussein, SH. M. (2009): Effect of Some exogenous chemical and biological electors compounds on systemic acquired resistance against fire blight symptoms, fruit quality and yield of le - Conte pear trees. J. Biol. Chem. Environ. Sci., 4 (1), 245-259.

$$
\begin{aligned}
& \text { تحسين جودة ثمار أشجار التفاح " صنف أنا " النامي على أصل مالص ببعض المركبات الحيوية } \\
& \text { محمد يحي ، أشرف عبد الباري ، عزه إبراهيم محمد } \\
& \text { معهد بحوث البساتين - مركز البحوث الزراعية - الجيزة - مصر ، معرد }
\end{aligned}
$$

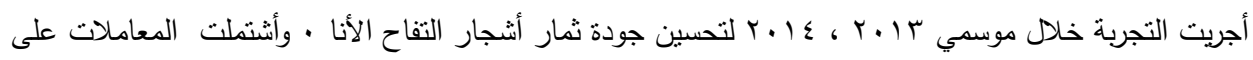

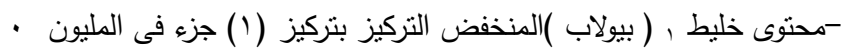

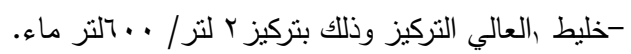

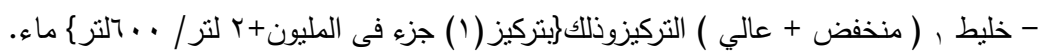

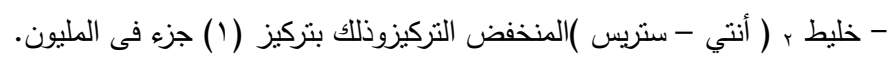

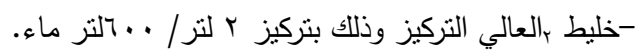

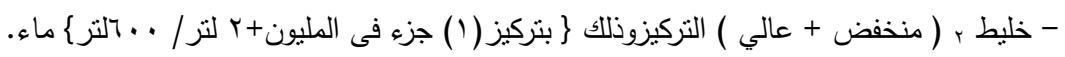

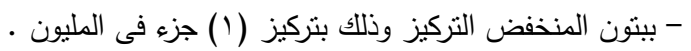

$$
\begin{aligned}
& \text { - بيتون العالي التركيز وذلك بتركيز ب جرام/ لتر ماء. } \\
& \text { - والكنترول \}الرش بالماء\{. } \\
& \text { أثنارت النتائج أن معاملات خليط > ( منخفض + عالي ) التركيز والبيتون أعطى أعلى عدد معنوي من الثمار بالنسبة للشجرة · خليط r ( } \\
& \text { منخفض + عالي ) التركيز والبيتونوخليط امنخفض التركيز أعطى أعلى محصول معنوي · خليط, أعطى أعلى وزن معنوي للثمرة · نسبة }
\end{aligned}
$$

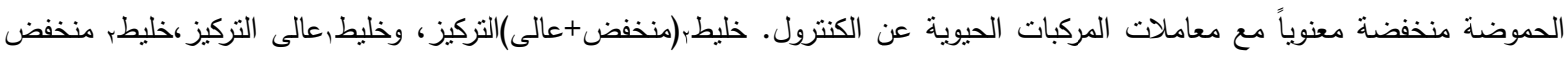

$$
\begin{aligned}
& \text { التركيز كان تأثيرهماإيجابى على لون الثمار. الفينولات الكليه كانت أعلى معنوياً مع الكونترول. البروتين الكلى كان أعلى معنوياً مع خليطه. }
\end{aligned}
$$

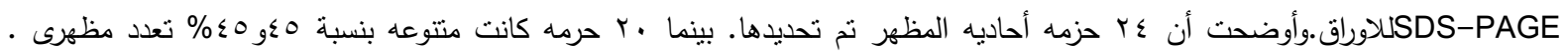

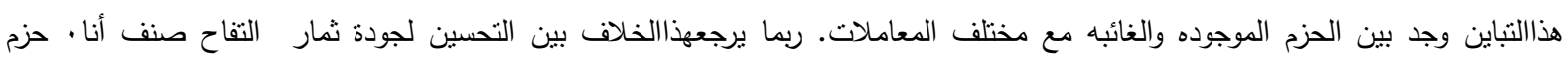

$$
\begin{aligned}
& \text { الآنزيمات مع أنزيم البولى فينول أوكسيديز (PPO) والبيوكسيديز (PX) تباينت بين المعاملات تحت الدراسه. } \\
& \text { ويمكن التوصيه بالإتى:- }
\end{aligned}
$$

الرش بالمركبات الحيويه حسنت جودة الثمار لصنف التفاح الانا • كما أن خليط ب(منخفض +عالى ) التركبز وخليط , المنخفض التركيزوكذلك

$$
\text { الببتون حسن المحصول وجودة الثمار • بالت }
$$

